\title{
STIMULATION OF THE GERBIL'S GUSTATORY RECEPTORS BY SACCHARIN $^{1}$
}

\author{
WILLIAM JAKINOVICH, JR. ${ }^{2}$
}

Department of Biological Sciences, Herbert H. Lehman College, The City University of New York, Bronx, New York 10468

Received August 12, 1981; Accepted September 15, 1981

\begin{abstract}
The gustatory responses from the chorda tympani nerve of the Mongolian gerbil, Meriones unguiculatus, were tested with saccharin and some closely related compounds. Only two compounds, saccharin and 6-chlorosaccharin, stimulated the gerbil's taste receptors to any degree and in the same order in which they are sweet to man, saccharin $>6$-chlorosaccharin. Those compounds which are tasteless to man did not stimulate and included $N$-methyl saccharin, phthalimide, and $O$ sulfobenzoic acid. These nonstimulating derivatives did not inhibit the saccharin electrophysiological response. The saccharin taste response $\mathrm{pH}$ optimum is from 5 to 8 . At $\mathrm{pH} 7$ and 8 , saccharin is fully ionized and is binding to the receptor site by an anionic mechanism. Kinetic plots of the taste response at $\mathrm{pH} 7$ indicate that saccharin is forming 1:1 complexes with it. In addition, mixtures of saccharin and sucrose stimulate in such a manner as to suggest that they are interacting at different receptor sites.
\end{abstract}

In a previous study (Jakinovich, 1981), data were accumulated on the gerbil's taste response to a group of artificial sweeteners, including saccharin. We tested them both behaviorally and electrophysiologically, anticipating uniform responses because sweetness in humans is unified under Shallenberger and Acree's (1967) "AH,B" theory. This proved not to be the case. Of the 21 sweeteners tested electrophysiologically, only 14 stimulated the gerbil's taste nerve, and of those 14, 6 did not taste like sucrose according to behavioral experiments.

The purpose of the present investigation was to focus on the gerbil's taste response to saccharin. This sweetener is important not only because it stimulates the gerbil's taste nerve and resembles the taste of sucrose behaviorally (Jakinovich, 1981) but because, in mammals, it is the most uniformly preferred artificial sweetener (Jakinovich, 1980), indicating a common sweet taste receptor mechanism. With regard to this mechanism, there is the intriguing possibility that saccharin and sugars are stimulating the taste receptors through separate receptor sites (Zawalich, 1973). With that in mind, this experiment compared taste responses to both tasteless and sweet saccharin derivatives. Also, a mixture experiment was conducted to determine if sucrose and

\footnotetext{
${ }^{1}$ This work was supported by Grant RO1 NS16022-01 from the National Institutes of Health.

${ }^{2}$ To whom correspondence should be addressed at Department of Biological Sciences, Herbert H. Lehman College, The City University of New York, Bedford Park Boulevard West, Bronx, NY 10468.
}

saccharin were interacting at the same or at different receptor sites. Finally, a pH experiment was conducted because saccharin's amide group (the " $\mathrm{AH}$ " group of Shallenberger and Acree (1967)) will ionize depending upon the $\mathrm{pH}$ and the results could shed some light on the binding mechanism.

The results of these experiments suggest that the gerbil's taste specificity to saccharin is the same as man's inasmuch as the taste responses were similar. The saccharin derivatives which taste sweet to man also stimulated the gerbil's taste receptors, and the tasteless ones did not stimulate. However, it would seem that the taste stimulation mechanism is not consistent with the "AH,B" theory. We have found that the saccharin taste response has a pH optimum range from 5 to 8 . At $\mathrm{pH} 7$ and 8 , saccharin is fully ionized, lacks the $\mathrm{AH}$ group, and therefore, cannot be forming hydrogen bonds with the receptor site. Moreover, contrary to the theory, mixtures of sucrose and saccharin stimulated in such a manner as to suggest that they were interacting at different receptor sites.

\section{Materials and Methods}

\section{Animals}

The Mongolian gerbils, Meriones unguiculatus, were obtained from the Tumblebrook Farm, West Brookfield, MA, included both sexes, were less than 1 year old, and weighed 45 to $70 \mathrm{gm}$. 


\section{Stimuli}

Compounds. Sodium saccharin was obtained from Fisher Scientific Co., Fairlawn, NJ. H-Saccharin (free acid), 6-chlorosaccharin, $O$-sulfobenzoic acid cyclic anhydride, and phthalimide were obtained from the Aldrich Chemical Co., Milwaukee, WI.

$N$-Methyl saccharin was prepared by dissolving $20 \mathrm{gm}$ of sodium saccharin in $20 \mathrm{ml}$ of $\mathrm{N}, \mathrm{N}$-dimethylformamide to which $20 \mathrm{ml}$ of methyl iodide were added. The reaction was allowed to continue for $18 \mathrm{hr}$ at room temperature. The resulting solid mass of crystals was placed into 100 $\mathrm{ml}$ of water and extracted twice with $20 \mathrm{ml}$ of ethyl ether. The ether extracts were dried, yielding $16 \mathrm{gm}$ of needle crystals. They were recrystallized twice from $95 \%$ ethanol and had a melting point of 130 to $131^{\circ} \mathrm{C}$ which agrees with the literature (Cohn, 1914).

Taste solutions. Taste solutions were prepared by dissolving the compound in deionized water or one of several potassium buffer solutions and were used immediately or stored at $2^{\circ} \mathrm{C}$ up to 7 days for later use, at which time, they were brought to room temperature. The potassium buffers were used because they produced small transitory taste responses which adapted completely within a few seconds. These buffers were prepared from mixtures of $0.1 \mathrm{M}$ salts or acid which formed one of the following buffer pairs (Gomori, 1955): the phosphate buffers (pH 5 to 8.9) from $\mathrm{KH}_{2} \mathrm{PO}_{4} / \mathrm{K}_{2} \mathrm{HPO}_{4}$, the citrate buffer (pH 3 and 4) from citric acid in $0.1 \mathrm{M} \mathrm{KCl} / \mathrm{K}$ citrate, or carbonate-bicarbonate buffer $(\mathrm{pH} \mathrm{10)}$ from $\mathrm{K}_{2} \mathrm{CO}_{3} / \mathrm{KHCO}_{3}$. The $\mathrm{pH}$ values were checked by a $\mathrm{pH}$ meter and were adjusted by adding one of the appropriate buffer pairs.

\section{Electrophysiology}

The method for exposing and recording from the intact chorda tympani nerve has been reported (Jakinovich and Oakley, 1975). The recording was done by touching the nerve with a Nichrome electrode (100 $\mu \mathrm{m}$ diameter) which was connected to a differential amplifier (Grass P511). The neural activity was displayed on an oscilloscope and monitored by means of a loudspeaker. The integrated discharge of the nerve was used to characterize the gustatory system since it represented a summation of activity from many receptor cells (Kimura and Beidler, 1961). A response in this study was defined as the difference between spontaneous activity and the greatest integrated potential elicited by a given solution applied to the tongue. The integrator's (Grass model 73PA) time constant was set at $0.5 \mathrm{sec}$, full wave rectification. The indifferent electrode was placed on a nearby piece of moist tissue within the auditory bulla.

Stimulation. Chemical stimulation of the tongue was effected by a gravity flow funnel tubing system in which deionized water or a buffered solution was flowing $(0.13$ to $0.17 \mathrm{ml} / \mathrm{sec}$ ) over it. Test solutions $(2$ to $4 \mathrm{ml}$ ) were alternated with water without interruption of the flow. The temperature of the water and of the taste solution was identical, $25 \pm 1^{\circ} \mathrm{C}$.

The compounds were tested twice in an increasing $1 / 2$ log molar concentration series with a standard solution ( $0.3 \mathrm{M}$ sucrose or $0.01 \mathrm{M}$ saccharin) in between each series to assess response stability. Whenever the standard so- lution elicited responses differing by more than $10 \%$, all interjacent responses were rejected.

Concentration-response curves. Each animal was presented with a concentration series of sucrose which allowed computation of the responses of each saccharin compound to be expressed as a percentage of the maximum sucrose response. Determination of the dissociation constant $\left(K_{d}\right)$ and maximum response $\left(\operatorname{Resp}_{\max }\right)$ was accomplished by means of a reciprocal plot.

Theoretical curves for the responses (Resp) to a mixture of sucrose (suc) and saccharin (sac) were drawn from the following equations:

Equation 1: Interaction of two substances with one receptor site (Jakinovich and Goldstein, 1976)

$$
\frac{\operatorname{Resp}}{\operatorname{Resp}_{\max }}=\frac{K_{\mathrm{suc}}[\mathrm{sac}]+K_{\mathrm{sac}}[\mathrm{suc}]}{K_{\mathrm{suc}}[\mathrm{sac}]+K_{\mathrm{sac}}[\mathrm{suc}]+\left[K_{\mathrm{suc}}\right]\left[K_{\mathrm{sac}}\right]}
$$

Equation 2: Interaction of two substances with two independent receptor sites and effector systems (Ariens et al., 1956)

$$
\operatorname{Resp}_{\text {mixture }}=\operatorname{Resp}_{\text {suc }}+\operatorname{Resp}_{\text {sac }}
$$

Equation 3: Interaction of two substances with two independent receptor sites through a common effector system which limits the maximum response (Ariens et al., 1956)

$$
\text { Resp }_{\text {mixture }}=\operatorname{Resp}_{\text {suc }}+\operatorname{Resp}_{\text {sac }}-\frac{\left[\operatorname{Resp}_{\mathrm{suc}}\right]\left[\operatorname{Resp}_{\mathrm{sac}}\right]}{\text { Maximum Resp } p_{\text {mixture }}}
$$

\section{Results}

\section{Experiments in deionized water solutions}

H-Saccharin was found to be a better taste stimulus than either sodium saccharin or sucrose (Fig. 1). The limited solubility of $\mathrm{H}$-saccharin prevented our testing it at concentrations higher than $10^{-2} \mathrm{M}$. Sodium saccharin and sucrose were tested up to $1.0 \mathrm{M}$ and produced responses which reached maximum values.

\section{Experiments comparing buffered solutions to deionized water solutions}

Since H-saccharin is acidic (Table I), a property which could confound the results, we decided to use buffers.

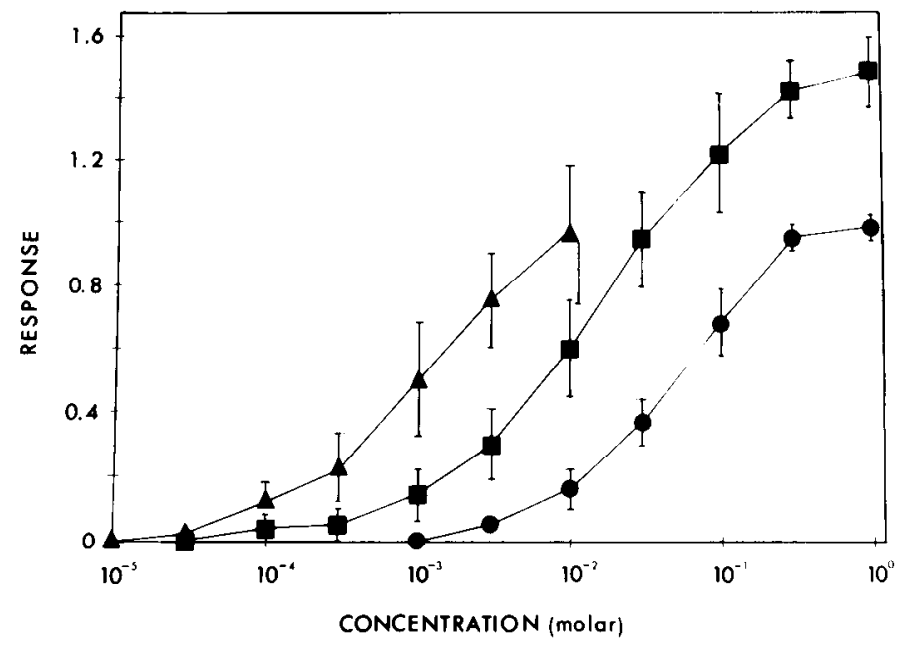

Figure 1. Mean integrated chorda tympani nerve response to sucrose (O), $N=8$; $\mathrm{H}$-saccharin $(\Delta), N=5$; and sodium saccharin ( $\square), N=7$, dissolved in deionized water. The bars indicate $\pm 2 \mathrm{SE}$. 
First, an experiment was conducted to determine whether the $\mathrm{pH}$ buffer would affect the taste responses to the standard sucrose solution, which is usually dissolved in deionized water. The mean responses to sucrose solutions were unaffected by the buffer, whereas those to $\mathrm{H}$-saccharin were diminished significantly by the buffer (Fig. 2). However, in both experiments, responses to buffered solutions showed a smaller standard deviation, indicating less variability in the taste responses. The differences observed were due to diminished responses to saccharin but not to the standard sucrose solutions (Fig. 3).

TABLE I

Physical properties of saccharin taste solutions in deionized water

\begin{tabular}{ccccc}
\hline \multirow{2}{*}{$\begin{array}{c}\text { Saccharin } \\
\text { Concentration }\end{array}$} & \multicolumn{2}{c}{ H-Saccharin } & & $\begin{array}{c}\text { Sodium } \\
\text { Saccharin }\end{array}$ \\
\cline { 2 - 3 } & $\mathrm{pH}$ & $\mathrm{H}$ & $\mathrm{pH}$ \\
\hline $0^{a}$ & 7.53 & $3 \times 10^{-8}$ & \\
$10^{-5}$ & 7.72 & $1.9 \times 10^{-8}$ & & 7.53 \\
$3 \times 10^{-5}$ & 5.02 & $9.6 \times 10^{-6}$ & & 7.70 \\
$10^{-4}$ & 4.30 & $5.0 \times 10^{-5}$ & \\
$3 \times 10^{-4}$ & 3.03 & $9.3 \times 10^{-4}$ & 6.09 \\
$10^{-3}$ & 2.90 & $1.3 \times 10^{-3}$ & \\
$3 \times 10^{-3}$ & 2.42 & $3.8 \times 10^{-3}$ & 6.71 \\
$10^{-2}$ & $2.2^{b}$ & $6.3 \times 10^{-3}$ & 6.20 \\
$3 \times 10^{-2}$ & & & 6.31 \\
$10^{-1}$ & & & 6.30 \\
$3 \times 10^{-1}$ & & & 6.40 \\
$10^{0}$ & & & 6.48 \\
\hline
\end{tabular}

${ }^{a}$ Freshly deionized $\mathrm{H}_{2} \mathrm{O}$.

${ }^{b}$ Nearly saturated solution.

\section{Experiments in buffered solutions}

Saccharin. In $0.1 \mathrm{M}$ potassium phosphate buffer $(\mathrm{pH}$ 7), H-saccharin was found to be slightly more soluble $\left(10^{-1} \mathrm{M}\right)$ than in deionized water $\left(10^{-2} \mathrm{M}\right)$. Because of this, it could be tested at a higher concentration and was found to produce responses which reached a mean maximum value $\left(R_{\max \text { sac }}=1.02\right)$. This was slightly more than the sucrose maximum response $\left(R_{\max \text { suc }}=0.98\right)$. When the saccharin responses were plotted on double reciprocal plots (Fig. 4) or Beidler plots (Beidler, 1954), they approximated straight lines which were parallel to the

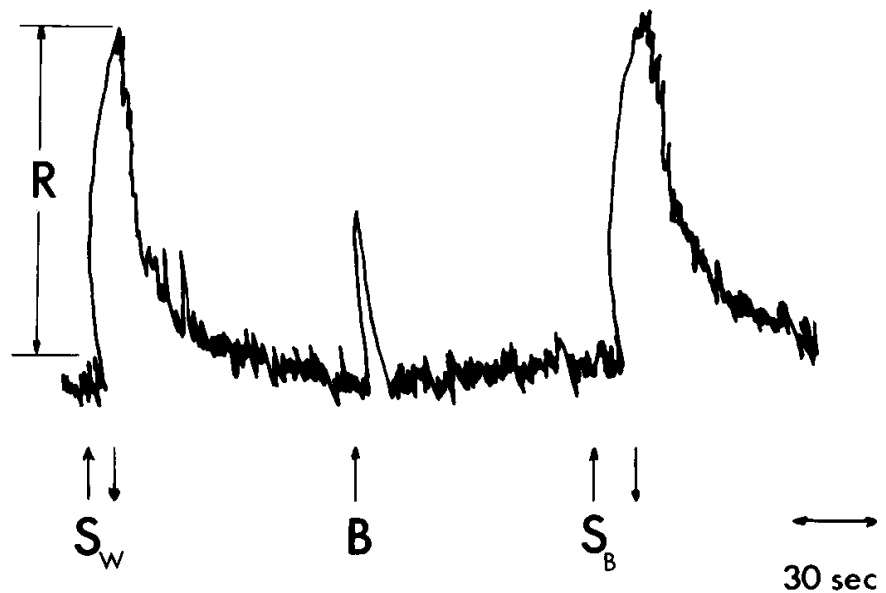

Figure 3. Integrated nerve response $(R)$ of $0.3 \mathrm{~m}$ sucrose dissolved in water $\left(S_{W}\right)$ and dissolved in $0.1 \mathrm{M}$ potassium phosphate buffer, $\mathrm{pH} 7\left(S_{B}\right)$. The buffer $(B)$ produces a small response which rapidly adapts. The up arrow $(\uparrow)$ indicates the addition of the stimuli to the flow system and the down arrow $(\downarrow)$ indicates the addition of the rinse (either water or buffer) to the flow system.

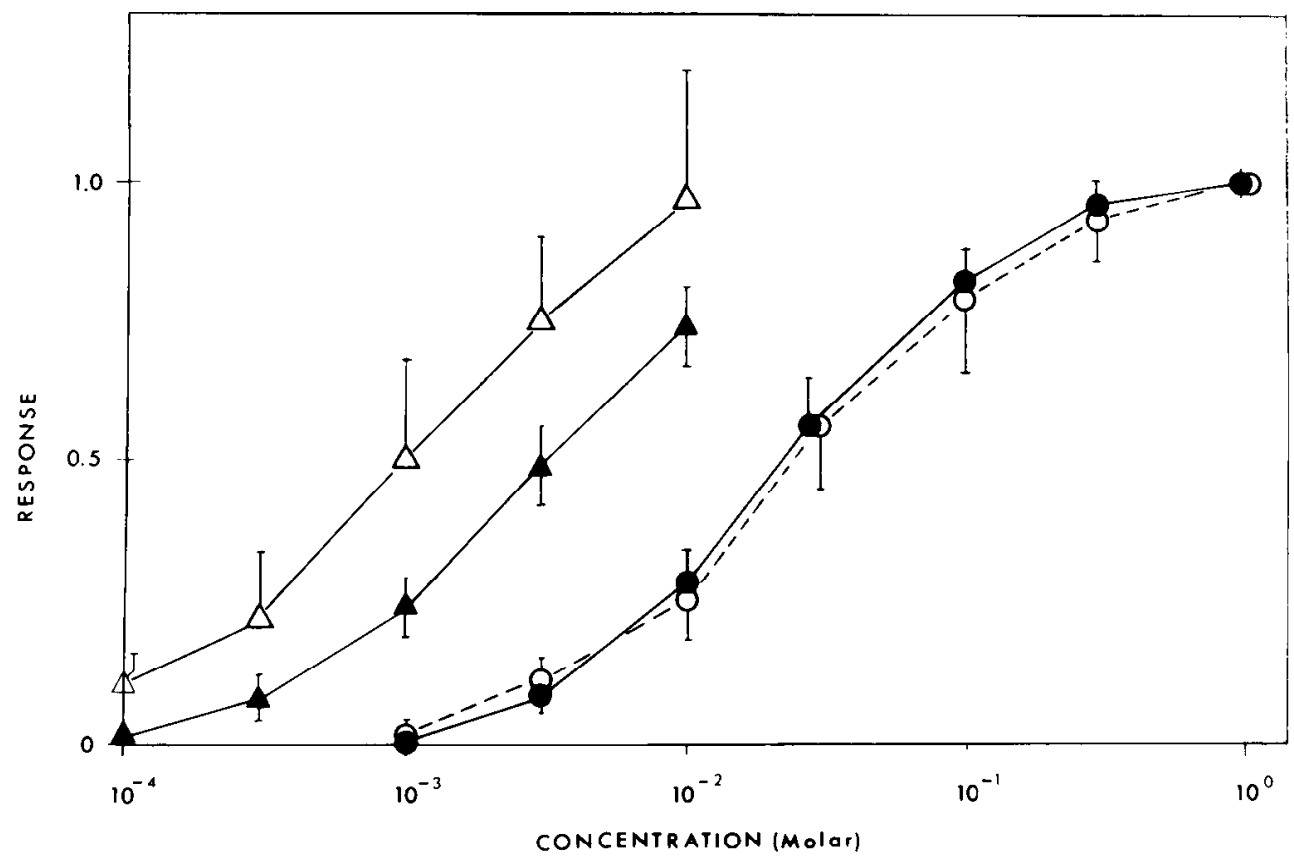

Figure 2. Comparison of mean integrated nerve responses to taste solution dissolved in deionized water with those dissolved in $0.1 \mathrm{M}$ potassium phosphate buffer, $\mathrm{pH} 7 . \mathrm{O}$, Sucrose in deionized water, $N=7 ; 0$, sucrose in buffer, $N=7 ; \triangle$, H-saccharin in deionized water, $N$ $=5 ; \Delta, \mathrm{H}$-saccharin in buffer, $N=11$. The bars indicate $\pm 2 \mathrm{SE}$. 
sucrose response. Determined from the slope, the dissociation constants for saccharin $\left(K_{d}=3.3 \times 10^{-3} \mathrm{M}\right)$ and sucrose $\left(K_{d}=2.9 \times 10^{-2} \mathrm{M}\right)$ are in close agreement with the $\mathrm{CR}_{50}$ values which are measured directly from the concentration-response curves (saccharin $\mathrm{CR}_{50}=3.4 \times$ $10^{-3} \mathrm{M}$ and sucrose $\mathrm{CR}_{50}=2.5 \times 10^{-2} \mathrm{M}$ ). A Hill plot (Hill, 1910) of the data produced a straight line with a slope of nearly 1 for both sweeteners.

Derivatives. Five compounds which resemble saccharin were tested (Table II) and only the two which are sweet to man, saccharin and 6-chlorosaccharin, stimulated the gerbil's taste receptors to any degree and in the same order in which they are sweet to man, saccharin $>$ 6-chlorosaccharin (De Roode, 1891).

Mixtures: Saccharin and nonstimulating derivatives. The taste responses to $0.001 \mathrm{M} \mathrm{H}$-saccharin (in $0.1 \mathrm{M}$ potassium phosphate buffer, $\mathrm{pH}$ 7) were not affected by

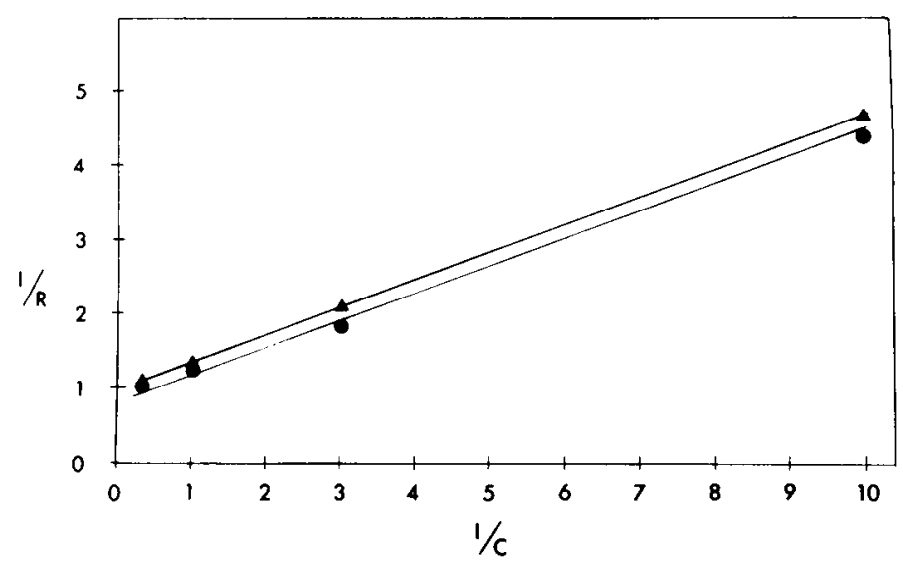

Figure 4. Reciprocal plot of integrated nerve responses to saccharin $(\Delta)$ and sucrose $(O)$ dissolved in $0.1 \mathrm{M}$ potassium phosphate buffer, pH 7. The slope is $K_{d} / \operatorname{Resp}_{\max } ; K_{d}$ is the dissociation constant, Resp $\max _{\max }$ is the maximum response, and $1 / R_{\max }$ is the $y$ intercept. The sucrose $1 / C$ is $\times 10^{-2} \mathrm{M}^{-1}$ and saccharin $1 / C$ is $\times 10^{-3} \mathrm{M}^{-1}$. Data are from Figure 5 . the presence of $N$-methyl saccharin, $O$-sulfobenzoic acid, or phthalimide. Because phthalimide is slightly ionized (4.5\%) at $\mathrm{pH} 7$, a second mixture experiment was conducted at its $\mathrm{pK}(\mathrm{pH} 8.3$, Stecher, 1968) where it is $50 \%$ ionized, and as observed at $\mathrm{pH} 7$, phthalimide did not inhibit the H-saccharin response. Phthalimide alone did not produce a taste response at $\mathrm{pH} 8.3$.

Mixtures: Saccharin and sucrose. The taste responses evoked by a mixture of $3 \times 10^{-2} \mathrm{M} \mathrm{H}$-saccharin and increasing concentrations of sucrose were fitted to theoretical curves representing three possible mechanisms: (1) interactions of two compounds at a single receptor site, (2) involvement of two receptor sites with no interaction between sites, and (3) involvement of two independent receptor sites with functional interaction. Our results fit possibility 3 (Fig. 5).

Effect of $p H$. Altering the $\mathrm{pH}$ has different effects on taste responses produced by saccharin, sucrose, and sodium chloride (Fig. 6). The optimum $\mathrm{pH}$ range of the saccharin responses proved to be 5 to 8 . The sucrose optimum $\mathrm{pH}$ range proved to be from 6 to 10 . In contrast to the two sweeteners, the sodium chloride response was unaffected over the entire $\mathrm{pH}$ range tested. Taste solutions of all of the compounds could not be tested at higher than $\mathrm{pH} 10$ or lower than $\mathrm{pH} 3$ because the spontaneous activity which is usually constant became very erratic when a solution outside of this $\mathrm{pH}$ range was applied to the tongue.

\section{Discussion}

The results of these chorda tympani electrophysiological experiments are consistent with those obtained from other mammals. For example, sodium saccharin produces electrophysiological responses in the gerbil as it does in many other mammals (Jakinovich, 1980). The gerbil's sodium saccharin taste threshold $(0.0001 \mathrm{M})$ is in the same range as those measured in the macaque monkey (0.0002 M; Ogawa et al., 1972), the hamster $(0.0001 \mathrm{M}$;

TABLE II

Summary of gerbil electrophysiological experiments with sucrose and some saccharin derivatives All of the electrophysiological experiments were conducted with taste stimuli dissolved in $0.1 \mathrm{M}$ potassium phosphate buffer, $\mathrm{pH} 7.0$.

\begin{tabular}{|c|c|c|c|c|}
\hline Compound & Threshold $^{a}$ & $K_{d}$ & $\begin{array}{c}\text { Highest } \\
\text { Concentration } \\
\text { Tested }\end{array}$ & $\begin{array}{l}\text { Sweetness }{ }^{b} \text { to Man } \\
\quad(\times \text { Sucrose })\end{array}$ \\
\hline \multicolumn{5}{|c|}{$M$} \\
\hline Sucrose & $3 \times 10^{-3}$ & $2.9 \times 10^{-2}$ & 1.0 & 1 \\
\hline $\begin{array}{r}\text { Saccharin-H } \\
\text { (free acid) }\end{array}$ & $3 \times 10^{-4}$ & $3.3 \times 10^{-3}$ & $1 \times 10^{-1}$ & $\begin{array}{c}200-700^{c} \\
(\text { Beck, 1974) }\end{array}$ \\
\hline $\begin{array}{l}\text { 6-Chlorosaccharin } \\
\text { (free acid) }\end{array}$ & $1 \times 10^{-3}$ & $9 \times 10^{-3}$ & $1 \times 10^{-2}$ & $\begin{array}{c}100-350 \\
\text { (Beck, 1974) }\end{array}$ \\
\hline$N$-Methyl saccharin & $\ldots d$ & $-^{e}$ & $3 \times 10^{-2}$ & $\begin{array}{c}\text { Tasteless } \\
\text { (Cohn, 1914) }\end{array}$ \\
\hline $\begin{array}{l}\text { Phthalimide-H } \\
\text { (potassium salt) }\end{array}$ & - & - & $\begin{array}{r}2.4 \times 10^{-4} \\
\left(1 \times 10^{-2}\right)\end{array}$ & $\begin{array}{c}\text { Tasteless } \\
\text { (Holleman, 1923) }\end{array}$ \\
\hline$O$-Sulfobenzoic acid & - & - & $1 \times 10^{-2}$ & Tasteless ${ }^{\prime}$ \\
\hline
\end{tabular}

a Threshold is the concentration at which $50 \%$ of the animals responded.

${ }^{h}$ The sweetness of a compound was determined by its threshold or by matching its sweetness to that of a sucrose solution.

${ }^{\mathrm{c}}$ Sodium salt.

${ }^{d}$ Small, barely perceptible response.

${ }^{e}$ Did not stimulate.

${ }^{\prime}$ We found this compound tasteless in buffer and sour in deionized water. This compound was prepared by dissolving $O$-sulfobenzoic acid cyclic anhydride in water. 


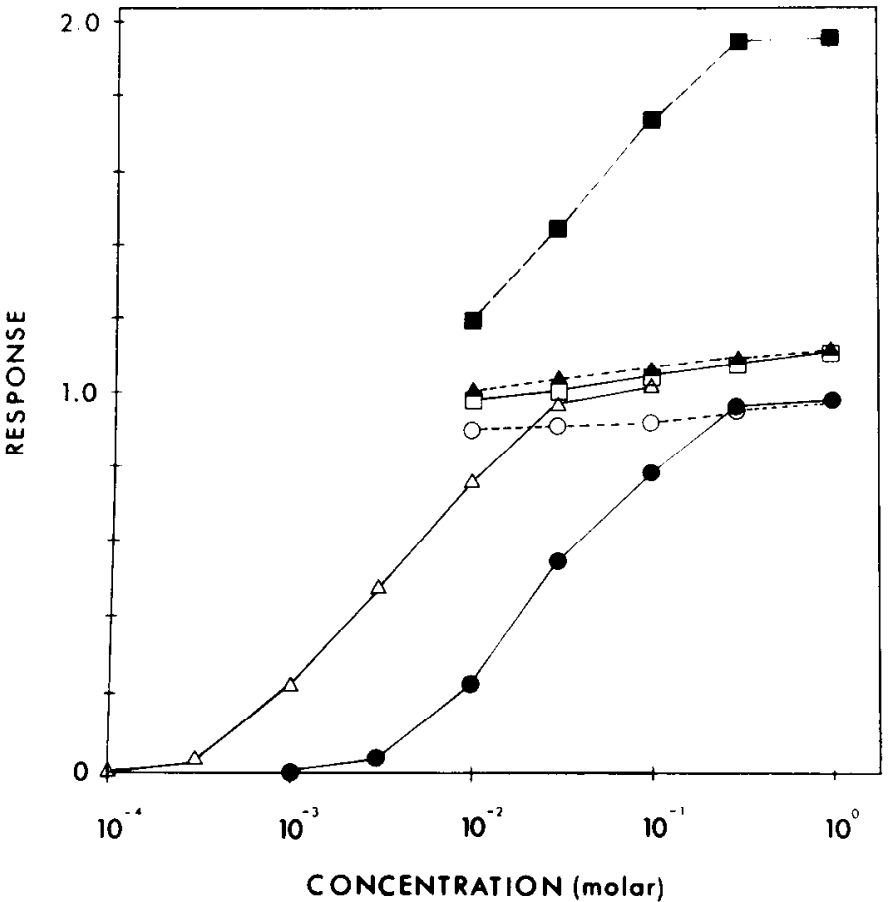

Figure 5. Concentration-response curve of sucrose in the presence of saccharin. The dashed lines are theoretical curves obtained from an equation describing (1) the competitive interaction of two substances with a single receptor site $(O),(2)$ independent receptor sites ( $\square$ ), and (3) independent receptor sites with functional interaction $(\boldsymbol{A})$. Also shown are data points for sucrose alone $(O)$, saccharin alone $(\triangle)$, sucrose $+3 \times 10^{-2} \mathrm{M}$ saccharin ( $\square) ; N=5$. Standard error bars are not shown to simplify figure. The solvent is $0.1 \mathrm{M}$ potassium phosphate buffer, pH 7.

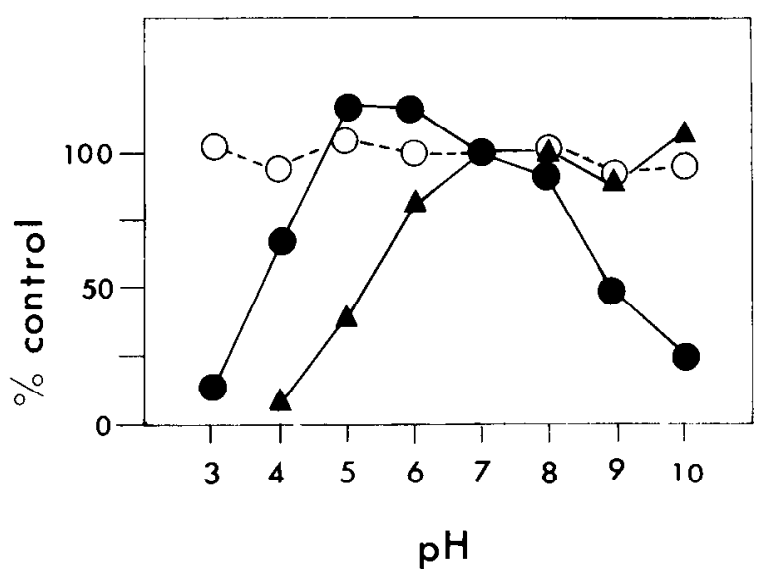

Figure 6. The effect of $\mathrm{pH}$ on the taste response to $0.1 \mathrm{M}$ sodium chloride $(\mathrm{O}), 0.001 \mathrm{M} \mathrm{H}$-saccharin (O), and $0.03 \mathrm{M}$ sucrose $(\mathbf{A})$. The concentrations chosen produce nearly equivalent responses. The control response is the response of a substance dissolved in $0.1 \mathrm{M}$ potassium phosphate buffer, $\mathrm{pH} 7$.

Hardiman, 1964), and the rat $(0.0003 \mathrm{~m}$; Ogawa et al., 1969). The maximum responses recorded for sucrose $\left(R_{\max }=0.98\right)$ and sodium saccharin $\left(R_{\max }=1.5\right)$ are in agreement with those obtained in an earlier gerbil experiment (Jakinovich, 1981) and close to those obtained by Hardiman (1964) from the hamster, sucrose $R_{\max }=1.0$ and sodium saccharin $R_{\max }=1.4$. With regard to the taste response to $\mathrm{H}$-saccharin (dissolved in deionized water), the gerbil results resemble those obtained from the hamster in that $\mathrm{H}$-saccharin produces steeper response curves than sodium saccharin (Hardiman, 1964). The steepness of the response is attributable to the stimulation of the taste nerve by hydrogen ions.

The effects of $\mathrm{pH}$ on the gerbil's taste responses are in general agreement with those obtained in other mammals. For example, in agreement with what we observed by stimulating the whole nerve of the gerbil, Ogawa et al. (1969) found that the saccharin response in a single taste neuron in the rat is depressed at a low $\mathrm{pH}$. In addition, Ogawa (1969) observed that the sucrose response was unaffected by $\mathrm{pH}$ over the range of 5 to 11 but became depressed at $\mathrm{pH} 3$ and 4 . In our experiment, the sucrose response was unaffected at $\mathrm{pH} 6$ to 10 but became depressed at $\mathrm{pH} 4$ and 5 . The difference may be attributable to different animals or slightly different methods. We continually bathed the tongue in buffer solution and thereby preadapted the receptors to the buffer, whereas Ogawa alternated a deionized water flow with a mixture of sugar and hydrochloric acid or sodium hydroxide (used to adjust $\mathrm{pH}$ ). He measured a stimulus response by subtracting the acid response, obtained separately, from the total response. With regard to sodium chloride, our results are the same as those obtained in rats by Beidler (1954).

When Beidler formulated his taste theory (1954), he envisioned a single stimulus molecule binding to a single receptor site to form a stimulus-receptor complex. He assumed that the integrated chorda tympani nerve response was proportional to the number of interactions or complexes formed between the stimulus and the receptor site. In line with this hypothesis, the gerbil's chorda tympani nerve responses to saccharin are consistent with the mechanism proposed by Beidler because they fit a straight line in the reciprocal plot and have a slope of 1 in the Hill plot.

In further pursuit of this theory, we discovered, by using mixtures of saccharin and sucrose, that each was binding to a different site. This agrees with electrophysiological experiments in the rat where two receptor sites have been postulated to account for the alloxan depression of the sugar taste response but not of the taste responses of other sweeteners, such as sodium saccharin, sodium cyclamate, and glycine (Zawalich, 1973). The two receptor sites are independent and their combined $R_{\max }$ is limited by the response of the receptor or sensory neuron. This limitation could be within the taste receptor cell itself, such as a common pathway to the ionic channels or to neurosecretory processes, or the limitation could be within the primary sensory neuron where action potentials collide and cancel each other because of extensive dendrite branching (Bernard, 1972; Mistretta, 1972). From these types of experiments, we cannot tell if the saccharin and sucrose receptor sites occur on the same receptor cells. Information concerning saccharin and sucrose interaction with the single taste cell is not available, but macaque monkey single taste neuron studies have found neurons which respond to sucrose and to saccharin (Sato et al., 1975). (In addition, these workers report that the quinine-sensitive neurons respond to saccharin.) Single neurons which respond only to saccharin or sucrose were not found in this monkey. On the other hand, in 
gerbils and rats, in addition to neurons which respond to both saccharin and sucrose, single neurons which respond only to sucrose have been reported (Cheal et al., 1977; Ogawa et al., 1972). Like the monkey, no rodent taste neurons were found to respond only to saccharin. Those single neuron experiments suggest at least two types of sucrose sites in rodents, one which occurs by itself and one which accompanies a saccharin site. This interpretation may be too simplistic because of the extensive branching of the taste neuron dendrites and resulting synapses with more than one receptor cell (Beidler, 1969). Whether these branching neurons are innervating cells with one site or cells with two sites will have to await single taste receptor cell recordings.

One of the reasons for studying saccharin was that, next to sucrose, it is, in mammals, one of the most uniformly preferred sweeteners (a few exceptions have been noted by Beauchamp et al. (1977) and Kare (1971)). This uniformity suggests a common receptor mechanism, including specificity, for dealing with the taste of saccharin. The results of our specificity experiment support this notion. In man, saccharin is sweet, while $N$-methyl saccharin (Cohn, 1914), phthalimide (De Roode, 1891), and $O$-sulfobenzoic acid are tasteless. In the gerbil, saccharin is stimulatory, while the above-named derivatives fail to stimulate. In addition, the order of effectiveness as taste stimuli by the two stimulating derivatives is the same in both species, saccharin $>6$-chlorosaccharin (De Roode, 1891).

Another reason for studying saccharin taste was that the applicability to other mammals of the "Molecular Theory of Sweet Taste" in humans (Shallenberger and Acree, 1967) has been questioned (Jakinovich, 1981). According to the theory, a molecule will taste sweet if it possesses the "AH,B" system. This system consists of two electronegative atoms, A and B, separated by a distance of 2.5 to $4 \AA$. The $\mathrm{H}$ is a hydrogen atom attached to one electronegative atom by a covalent bond. The $\mathrm{A}$ and $B$ are usually an oxygen or nitrogen molecule but can be a carbon or chlorine molecule or thecenter of unsaturation. Then there must be a receptor site with a complementary "AH,B" system, such as a protein peptide bond or the free amino group of glutamine or asparagine, to which the sweet molecule can hydrogen bond. In saccharin, the amide group is the "AH" and one of the sulfuryl oxygen molecules is the "B." In sucrose, the "AH,B" could be almost any vicinal hydroxyl groups, but the $\mathrm{C}-3$ and $\mathrm{C}-4$ hydroxyl groups have been designated as the primary "AH,B" groups (Birch, 1976). The receptor sites are thought to be located in the membranes of the taste receptor cells.

The theory is elegantly simple and is applicable to the sweet taste of sugar but cannot account for the taste response to saccharin. A major reason is the possibility of separate receptor sites which is not accounted for by the theory. A second reason is that saccharin is ionized completely at $\mathrm{pH} 7$ and does not possess the crucial "AH" group (Table III). Even at pH 5 and 6, the fractional increase of un-ionized molecules is too small to account for the taste response.

With regard to the first reason, in addition to a sucrose site (Jakinovich and Oakley, 1976), we propose a separate
TABLE III

Physical properties and gerbil taste responses to $10^{-3} \mathrm{M} H$-saccharin in buffered taste solutions

\begin{tabular}{|c|c|c|c|c|}
\hline \multirow{2}{*}{\multicolumn{2}{|c|}{$\mathrm{pH}$}} & \multicolumn{2}{|c|}{$\begin{array}{c}\text { Degree of Ionization of } \\
\text { Saccharin }^{\alpha}\end{array}$} & \multirow{2}{*}{$\begin{array}{c}\text { Response } \\
\begin{array}{c}\text { Percent of } \\
\text { Control }\end{array}\end{array}$} \\
\hline & & $\begin{array}{l}\text { Percent } \\
\text { Ionized }\end{array}$ & $\begin{array}{c}\text { Percent } \\
\text { Un-ionized }\end{array}$ & \\
\hline 3 & \multirow{8}{*}{ (control) } & 86.32 & 13.68 & 14 \\
\hline 4 & & 98.44 & 1.56 & 66 \\
\hline 5 & & 99.84 & 0.16 & 118 \\
\hline 6 & & 99.98 & 0.02 & 114 \\
\hline 7 & & 100.00 & 0.00 & 100 \\
\hline 8 & & 100.00 & 0.00 & 91 \\
\hline 8.9 & & 100.00 & 0.00 & 50 \\
\hline 10 & & 100.00 & 0.00 & 26 \\
\hline
\end{tabular}

${ }^{a}$ Calculated from:

$$
\mathrm{pK}_{a}=\mathrm{pH}+\log \frac{\text { un-ionized }}{\text { ionized }}
$$

Saccharin $\mathrm{pK}_{a}=2.2$ (Kojima et al., 1966)

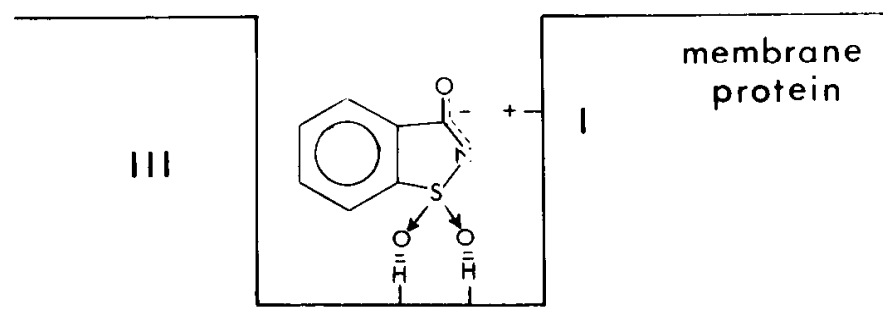

II

Figure 7. Proposed model for saccharin site in the membrane of the gerbil gustatory cell.

saccharin site as shown in Figure 7. The receptor possesses a cationic region $(I)$ which can form an ionic bond with the delocalized anionic region of saccharin (Crosby et al., 1979). This requirement partially explains the failure of $N$-methyl saccharin to stimulate the taste receptors because it is uncharged. The failure of $N$-methyl saccharin to stimulate also could be due to steric factors produced by the bulky methyl group. The saccharin receptor includes a pair of adsorption sites (II) for the sulfuryl oxygen molecules where binding may occur either through ion dipole or hydrogen bonding (Korolyovas, 1970). There appears to be a barrier (III) adjacent to the aromatic ring. This would account for the reduced responsiveness of 6-chlorosaccharin. The barrier is probably stereochemical in view of the fact that 6-substituted saccharin molecules are not as sweet as the unsubstituted molecule (Hamor, 1961). One puzzle is the failure of $O$ sulfobenzoic acid to stimulate despite being anionic and having the sulfuryl oxygen molecules. Perhaps this indicates that the isothiazol ring must be present to help align the substituents of saccharin with their adsorption sites (Holleman, 1923).

Ionization of the saccharin molecule and the presence of separate sucrose and saccharin receptor sites is borne out by the results of our $\mathrm{pH}$ experiments. Regarding the sucrose molecule, there is no $\mathrm{pH}$ effect. Sucrose's $\mathrm{pK}_{1}$ is 
12.6 (Urban and Shaffer, 1932), is mostly protonated at $\mathrm{pH} 3$ to 10 , and therefore, must be binding to the receptor site through complementary "AH,B" systems. With regard to the sucrose taste responses, the depression seen at $\mathrm{pH} 4$ and 5 results from the titration of the receptor site and subsequent unavailability of the "AH,B" system. With reference to saccharin, $\mathrm{pH}$ has a different effect on the degree of ionization of the saccharin molecule and must be taken into account when considering the effect of $\mathrm{pH}$ on the taste response to saccharin. In our experiments, as the $\mathrm{pH}$ of the saccharin solution is lowered (from 4 to 3), the taste response is depressed. This is the result of increased concentrations of un-ionized saccharin molecules which are poor stimuli according to our receptor site hypothesis. At higher $\mathrm{pH}$ values (above 8), the taste response also became depressed. This must be explained by the titration of the cationic sites within the saccharin receptor. (The saccharin molecule is unaffected by $\mathrm{pH}$ in this range.) At this point, it is apparent that $\mathrm{pH}$ has a double effect; in one range, it affects the receptor, and in another, it affects the stimulatory molecule. Inasmuch as we have described at least two pH effects which influenced our taste responses and since the taste system as a whole is such a complicated one, it is reasonable to assume that other factors also may be affected by $\mathrm{pH}$. Therefore, future investigations should consider all possibilities.

From an evolutionary point of view, one wonders at the very existence of a saccharin site. Perhaps saccharin's structure mimics that of some naturally occurring food substance. Or perhaps the receptor is a normal constituent of mammalian cell membranes (Price, 1974), such as transport proteins, that accidentally have an affinity for saccharin. In this vein, there are reports of saccharin transport in the urinary bladder and kidney of the rat (Colburn, 1978; Goldstein et al., 1978). Even more interesting is the report that saccharin and cyclamate inhibit the activity of glucose-6-phosphatase in rat liver (Lygre, 1974). Too little is known about the binding mechanism of the saccharin-glucose-6-phosphatase interaction, but it is worthy of further study in view of the exciting possible role of enzymes as taste receptors where most of the research in this area, particularly that involving insects, is concentrated (Hansen, 1969).

\section{References}

Ariens, E. J., J. M. van Rossum, and A. M. Simonis (1956) A theoretical basis of molecular pharmacology. Part III: Interaction of one or two compounds with two independent receptor systems. Arzneim. Forsch. 6: 737-746.

Beauchamp, G. K., O. Maller, and J. G. Rogers, Jr. (1977) Flavor preferences in cats (Felis catus and Panthera sp.). J. Comp. Physiol. Psychol. 91: 1118-1127.

Beck, K. M. (1974) Synthetic sweeteners: Past, present, and future. In Symposium: Sweeteners, G. E. Inglett, ed., pp. 131144, Avi Publishing Co., Inc., Westport, CT.

Beidler, L. M. (1954) A theory of taste stimulation. J. Gen. Physiol. 38: 133-139.

Beidler, L. M. (1969) Innervation of rat fungiform papilla. In Proceedings of the Third International Symposium on Olfaction and Taste, C. Pfaffmann, ed., pp. 352-353, Rockefeller University Press, New York.

Bernard, R. A. (1972) Antidromic inhibition: A new model of taste receptor function. In Olfaction and Taste, D. Schneider, ed., Vol. IV, pp. 301-307, Wissenschaftliche Verlagsgesellschaft $\mathrm{mbH}$, Stuttgart, Germany.

Birch, G. G. (1976) Structural relationships of sugars to taste. CRC Crit. Rev. Food Sci. Nutr. 8: 57-95.

Cheal, M., W. P. Dickey, L. B. Jones, and B. Oakley (1977) Taste fiber responses during reinnervation of fungiform pappillae. J. Comp. Neurol. 172: 627-646.

Cohn, G. (1914) Die Organischen Gesmackstoffe, p. 800, Siemenroth, Berlin.

Colburn, W. A. (1978) Absorption of saccharin from rat urinary bladder. J. Pharm. Sci. 67: 1493-1494.

Crosby, G. A., G. E. DuBois, and R. E. Wingard, Jr. (1979) The design of synthetic sweeteners. In Drug Design, E. J. Ariens, ed., Vol. VIII, pp. 215-310, Academic Press, New York.

De Roode, R. (1891) Investigations on the sulphinides. VII. On some derivatives of benzoic sulfinide, and the changes caused in their taste by changes in composition. Am. Chem. J. 13: 217-232.

Goldstein, R. S., J. B. Hook, and J. T. Bond (1978) Renal tubular transport of saccharin. J. Pharmacol. Exp. Ther. 204: 690-695.

Gomori, G. (1955) Preparation of buffers for use in enzyme studies. Methods Enzymol 1: 138-146.

Hamor, G. H. (1961) Correlation of chemical structure and taste in the saccharin series. Science 134: 1416-1417.

Hansen, K. (1969) The mechanism of insect sugar reception, a biochemical investigation. In Olfaction and Taste III, C. Pfaffmann, ed., pp. 382-391, Rockefeller University Press, New York.

Hardiman, C. W. (1964) Rat and hamster chemoreceptor responses to a large number of compounds and the formulation of a generalized chemosensory equation. Doctoral thesis, Florida State University, Tallahassee; University Microfilms, Ann Arbor, MI.

Hill, A. V. (1910) The possible effects of the aggregation of the molecules of haemoglobin on its dissociation curves. J. Physiol (Lond.) 40: iv-vii.

Holleman, A. F. (1923) On some derivatives of saccharin. Recl. Trav. Chim. Pay-Bas Belg. 42: 839-845.

Jakinovich, W., Jr. (1980) Comparative study of sweet taste specificity. In International Symposium on Biochemistry of Taste and Olfaction, R. H. Cagan and M. R. Kare, eds., pp. 117-137, Academic Press, New York.

Jakinovich, W., Jr. (1981) Stimulation of the gerbil's gustatory receptors by artificial sweeteners. Brain Res. 210: 69-81.

Jakinovich, W., Jr., and I. J. Goldstein (1976) Stimulation of the gerbil's gustatory receptors by monosaccharides. Brain Res. 110: 491-504.

Jakinovich, W., Jr., and B. Oakley (1975) Comparative gustatory response in four species of gerbilline rodents. J. Comp. Physiol. 99: 89-101.

Jakinovich, W., Jr., and B. Oakley (1976) Stimulation of the gerbil's gustatory receptors by polyols. Brain Res. 110: 505513.

Kare, M. (1971) Comparative study of taste. In Handbook of Sensory Physiology. Vol. IV: Chemical Senses. 2: Taste, L. M. Beidler, ed., pp. 278-292, Springer-Verlag, Berlin.

Kimura, K., and L. M. Beidler (1961) Microelectrode study of taste receptors of rat and hamster. J. Cell Comp. Physiol. 58: 131-139.

Kojima, S., H. Ichibagase, and S. Iguchi (1966) Studies on synthetic sweetening agents. VII. Absorption and excretion of sodium cyclamate. Chem. Pharm. Bull. (Tokyo) 14: 965971.

Korolyovas, A. (1970) Essentials of Molecular Pharmacology, pp. 137-138, Wiley Interscience, New York.

Lygre, D. G. (1974) The inhibition by saccharin and cyclamate of phosphotransferase and phosphohydrolase activities of 
glucose-6-phosphatase. Biochim. Biophys. Acta 341: 291-297.

Mistretta, C. M. (1972) A quantitative analysis of rat chorda tympani fiber discharge patterns. In Olfaction and Taste, $\mathrm{D}$. Schneider, ed., Vol. IV, pp. 294-300, Wissenschaftliche Verlagsgesellaschaft mbH, Stuttgart, Germany.

Ogawa, H. (1969) Effects of pH on taste responses in the chorda tympani nerve of rats. Jpn. J. Physiol. 19: 670-681.

Ogawa, H., M. Sato, and S. Yamashita (1969) Gustatory impulse discharges in response to saccharin in rats and hamsters. J. Physiol. (Lond.) 204: 311-329.

Ogawa, H., S. Yamashita, A. Noma, and M. Sato (1972) Taste responses in the macaque monkey chorda tympani. Physiol. Behav. 9: 325-331.

Price, S. (1974) Chemoreceptor proteins in taste cell stimula- tion. In Transduction Mechanisms in Chemoreception, $\mathrm{T}$. M. Poynder, ed., pp. 177-184, Information Retrieval Ltd., London.

Sato, M., H. Ogawa, and S. Yamashita (1975) Response properties of macaque monkey chorda tympani fibers. J. Gen. Physiol. 66: 781-810.

Shallenberger, R. S., and T. E. Acree (1967) Molecular theory of sweet taste. Nature 216: 480-482.

Stecher, P. G. (1968) Merck Index, Ed. 8, p. 827, Merck and Co., Inc., Rahway, NJ.

Urban, F., and P. A. Shaffer (1932) The acidic properties of sugars. J. Biochem. 94: 697-715.

Zawalich, W. S. (1973) Depression of gustatory sweet response by alloxan. Comp. Biochem. Physiol. (A) 44: 903-909. 